\title{
Keadilan Substantif Hakim Dalam Putusan Pengadilan Agama Kolaka Nomor: 2/Pdt.P/2010/PA Klk.
}

\section{Justice Substantive Judges In The Decision Of Kolaka Religious Court Number: 2/Pdt.P/2010/PA Klk.}

\author{
Andi Yusuf Syahrir \\ Universitas Sembilan Belas November \\ E-mail: andiyusufsyahrir@ymail.com \\ Deity Yuningsih \\ Pascasarjana Universitas Halu Oleo \\ E-mail: deityhukum@gmail.com \\ Idaman \\ Pascasarjana Universitas Halu Oleo \\ E-mail:idam_idea@uho.ac.id
}

\begin{abstract}
Judicial substantive consideration in the Decision of Kolaka Religious Court Number: 2/Pdt.P/2010/PA Klk. in determining the legal guardian is very appropriate, because in facts of the trial according to the Decision of Kolaka Religious Court Number: 2/Pdt.P/2010/Pa Klk., that the prospective husband of the applicant has 9 (nine) wives cannot be proven, so the applicant's parents refuse to marry the applicant is not true. In facts of the trial explained that there is no obstacle both state law and Islamic law that reject the marriage of the applicant and the prospective husband of the applicant, the bride and groom have also worked and are old enough and ready to get married. In order to avoid sins and other things that break the law, the marriage must be carried out even though the guardian is a marriage guardian. The marriage that was carried out was in accordance with Islamic law because it had fulfilled the harmonies. Thus, marriage is based on the decision of Kolaka Religious Court Number: 2/Pdt.P/2010/PA Klk. is legal.
\end{abstract}

Keywords: Justice; Judge; Marriage

Abstrak: Pertimbangan keadilan substantif Hakim dalam Putusan Pengadilan Agama Kolaka Nomor: 2/Pdt.P/2010/PA Klk.dalam menetapkan adhalnya wali sangat tepat, karena dalam fakta persidangan sesuai Putusan Pengadilan Agama Kolaka Nomor: 2/Pdt.P/2010/Pa Klk., bahwa calon suami pemohon memiliki 9 (sembilan) orang isteri tidak dapat dibuktikan, sehingga orang tua pemohon menolak untuk menikahkan pemohon adalah tidak benar. Dalam fakta persidangan 
menjelaskan bahwa tidak ada halangan baik hukum negara maupun hukum Islam yang menolak perkawinan pemohon dan calon suami pemohon, kedua mempelai juga telah bekerja dan cukup umur serta siap untuk menikah. Agar tidak terjadi perbuatan dosa dan hal-hal yang melanggar hukum, maka perkawinan harus dilaksanakan meskipun walinya adhal menjadi wali nikah. Perkawinan yang dilakukan telah sesuai dengan hukum Islam karena telah memenuhi rukunnya. Sehingga, perkawinan berdasarkan putusan Pengadilan Agama Kolaka Nomor: 2/Pdt.P/2010/PA Klk. adalah sah.

Kata kunci: Keadilan; Hakim; Perkawinan

\section{PENDAHULUAN}

Undang-Undang Nomor 1 Tahun 1974 Tentang Perkawinan pada Pasal 2 ayat (1) yang menyebutkan bahwa "Perkawinan adalah sah apabila dilakukan menurut hukum masingmasing agamanya dan kepercayaannya itu". Dalam penjelasan Pasal 2 ayat (1) ini, tidak ada perkawinan di luar hukum masing-masing agamanya dan kepercayaannya itu, sesuai dengan Undang-Undang Dasar 1945, yang dimaksud dengan hukum masing-masing agamanya dan kepercayaannya itu termasuk ketentuan perundang-undangan yang berlaku bagi golongan agamanya dan kepercayaannya itu sepanjang tidak bertentangan atau tidak ditentukan lain dalam Undang-Undang ini. Berdasarkan rumusan Pasal 2 ayat (1) Undang-Undang Nomor 1 Tahun 1974 Tentang Perkawinan, maka perkawinan bagi orang yang beragama Islam pelaksanaan perkawinannya harus didasarkan pada hukum perkawinan Islam ${ }^{1}$.

Dalam hukum perkawinan Islam diatur mengenai rukun perkawinan, yaitu hakikat dari suatu perkawinan, supaya perkawinan dapat dilaksanakan maka harus dipenuhi rukun-rukunya. Adapun rukun perkawinan adalah pihak yang melaksanakan akad nikah, yaitu mempelai pria dan wanita; Wali; Saksi; dan Akad nikah. ${ }^{2}$ Selain itu, seorang pria boleh menikah lebih dari satu istri sampai dengan empat istri bila dirinya mampu berbuat adil di antara istri-istrinya dan tidak berbuat zalim. Namun, diharamkan baginya untuk menikahi lebih dari 4 (empat) istri dalam satu waktu, sebagaimana dalam ayat Al-Qur'an surah An-Nisaa ayat 3, yang artinya:

"Dan jika kamu takut tidak akan dapat berlaku adil terhadap (hak-hak) perempuan yatim (bilamana kamu mengawininya), maka kawinilah wanitawanita (lain) yang kamu senangi, dua, tiga atau empat. Kemudian jika kamu takut

1 Saidus Syahar, Undang-Undang Perkawinan dan Masalah Pelaksanaannya, Bandung: Alumni, 1981, hlm. 27.

2 Soemiyati, Hukum Perkawinan Islam dan Undang-Undang Perkawinan, Yogyakarta: Liberty, 1986, hlm. 30. 
tidak akan dapat berlaku adil, maka (kawinilah) seorang saja, atau budak-budak yang kamu miliki." (An-Nisaa: 3)

Hal ini sesuai dengan hadis yang diriwayatkan oleh Abu Dawud dan Ibnu Majah dari Qais Ibnul Harits bahwa ia berkata: "Saya masuk Islam sementara saya memiliki 8 istri. Saya datang kepada Nabi shallallahu 'alaihi wasallam lalu saya ceritakan hal tersebut kepada beliau. Beliau pun berkata: 'Pilihlah olehmu di antara mereka empat orang saja'.3

Dalam hal ini wali nikah yang dimaksudkan adalah wali dari mempelai wanita. Wali nikah merupakan rukun, perkawinan tidak dapat dilaksanakan tanpa adanya wali nikah. Jika wali nikah itu adhal atau menolak untuk menikahkan, solusi yang dapat dilakukan adalah adanya wali hakim yang bertindak sebagai wali nikah setelah adanya keputusan dari pihak yang berwenang, salah satunya adalah keputusan hakim. Beberapa alasan yang menjadikan wali nikah menolak untuk menikahkan, contohnya menolak menikahkan karena perbedaan status sosial atau nilai mahar yang tidak dapat dipenuhi oleh calon mempelai pria.

Ketika wali nikah menolak untuk menikahkan, apabila mempelai wanita tetap berkehendak untuk menikah, maka solusi yang dapat dilakukan adalah mengadukan perkaranya kepada Pengadilan Agama sebagaimana diatur dalam Pasal 2 ayat 3 Peraturan Menteri Agama Nomor 2 Tahun 1987 Tentang Wali Hakim, bahwa "Pengadilan Agama memeriksa dan menetapkan adhal-nya wali dengan acara singkat atas permohonan calon mempelai dengan menghadirkan wali calon mempelai wanita.

Salah satu kasus wali adhal di Pengadilan Agama Kolaka yang memeriksa dan mengadili perkara wali adhal yang diajukan oleh pemohon berusia 37 tahun. Pemohon hendak melangsungkan perkawinan dengan laki-laki berusia 40 tahun namun ayah pemohon (wali nikah) menolak menikahkan dengan alasan laki-laki tersebut mempunyai 9 (sembilan) orang istri.

Berdasarkan penolakan tersebut, pemohon dan calon suaminya diberikan surat penolakan untuk dinikahkah dari Kepala KUA Kec. Kolaka. Atas dasar surat tersebut, Pemohon memohon kepada Pengadilan Agama Kolaka untuk diperiksa. Membaca surat permohonan pemohon tanggal 10 Desember 2010 yang diajukan kepada Ketua Pengadilan Agama Kolaka, kemudian terdaftar dalam bukur register perkara permohonan di bawah register Nomor: 2/Pdt.P/2010/PA klk., dimana pemohon memohon kepada

3 Muhammad Sholeh, "Kata MUI Soal Pria yang Beristri Lebih dari Empat", Merdeka.com, https://www.merdeka.com/peristiwa/kata-mui-soal-pria-yang-beristri-lebih-dari-empat.html, diakses pada tanggal 28 Juni 2020. 
Ketua Pengadilan Agama Kolaka untuk memeriksa dan mengadili perkara agar berkenan untuk:

1. Mengabulkan permohonan Pemohon;

2. Menyatakan wali pemohon sebagai wali adhal;

3. Mengizinkan pemohon untuk menikah dengan calon suami pemohon dengan wali hakim;

4. Membebankan biaya perkara kepada pemohon

Salah satu pertimbangan majelis hakim dalam mengabulkan permohonan pemohon adalah Pemohon tidak ada halangan untuk menikah baik dari segi hukum maupun dari segi syar'i. Hal ini perlu dilakukan analisis lebih lanjut, karena menyimak keterangan para saksi yang menyatakan jelas bahwa alasan orang tua/wali Pemohon menolak pernikahan dengan calon suaminya karena masih terikat perkawinan dengan 9 orang istri.

Tulisan ini bertujuan untuk menjawab bagaimana pertimbangan keadilan substantif Hakim dalam Putusan Pengadilan Agama Kolaka Nomor: 2/Pdt.P/2010/PA Klk.

\section{METODE PENELITIAN}

Tipe penelitian yang digunakan adalah tipe Normatif, yaitu dengan mengadakan penelitian yang mengkaji studi dokumen, menggunakan berbagai peraturan perundangundangan, keputusan pengadilan dan teori hukum. Pendekatan perundang-undangan, yakni Undang-Undang Republik Indonesia Nomor 1 Tahun 1974 tentang Perkawinan. Pendekatan perundang-undangan adalah pendekatan yang dilakukan dengan menelaah undang-undang, Kompilasi Hukum Islam maupun regulasi yang bersangkut paut dengan perkawinan dan perwalian.; ${ }^{4}$ pendekatan konseptual, yakni pendekatan dengan sudut pandang analisa penyelesaian permasalahan tentang perkawinan dengan wali adhal; dan pendekatan kasus, yakni pendekatan yang dilakukan dengan cara melakukan telaah terhadap kasus yang berkaitan dengan perkawinan dengan wali adhal dan telah menjadi putusan pengadilan Agama Kabupaten Kolaka.

\section{ANALISIS DAN PEMBAHASAN \\ Pengertian Perkawinan}

Pernikahan adalah aqd al-Tamlik, dapat pula diartikan aqd al-ibahah, pernikahan

4 Peter Mahmud Marzuki, Penelitian Hukum, Jakarta: Kencana Prenada Media Group, 2011, hlm. 24. 
diartikan membolehkan melakukan hubungan seksual antara suami dan istri tanpa ada kepemilikan secara penuh. ${ }^{5}$ Kata Nikah sudah menjadi bahasa Indonesia yang berasal dari bahasa Arab. Arti Nikah menurut bahasa Arab yang artinya bergabung dan berkumpul; dipergunakan juga dengan arti watha' atau akad nikah. Arti nikah menurut syara' ialah akad yang membolehkan seorang laki-laki bergaul bebas dengan perempuan tertentu dan pada waktu akad mempergunakan lafal "nikah" atau tazwij. ${ }^{6}$ Pengertian nikah/kawin dalam Undang-undang nomor 1 tahun 1974 tentang perkawinan dalam Pasal 1: "Perkawinan ialah ikatan lahir batin antara seorang pria dengan seorang wanita sebagai suami istri dengan tujuan membentuk keluarga (rumah tangga) yang bahagia dan kekal berdasarkan Ketuhanan Yang Maha Esa."

Menurut Sayuti Thalib, perkawinan ialah suatu perjanjian yang suci kuat dan kokoh untuk hidup bersama secara sah antara seorang laki-laki dengan seorang perempuan membentuk keluarga yang kekal, santun-menyantuni, kasih-mengasihi, tenteram dan bahagia. ${ }^{7}$ Sedangkan menurut Mahmud Yunus, yang dinamakan perkawinan adalah aqad antara calon laki-istri untuk memenuhi hajat jenisnya menurut yang diatur oleh syari'at. ${ }^{8}$

\section{Syarat-Syarat Perkawinan}

Perkawinan merupakan momentum yang penting dalam setiap kehidupan manusia. Untuk dapat melangsungkan perkawinan harus memenuhi beberapa syarat, sebelum melaksanakan suatu perkawinan yang harus dipenuhi. Maka di sini penulis akan mengemukakan mengenai syarat-syarat perkawinan.

\section{Syarat-syarat Perkawinan Menurut Hukum Islam}

Perbedaan antara syarat dan rukun perkawinan adalah bahwa rukun perkawinan adalah hakikat dari perkawinan, seperti laki-laki, perempuan, wali nikah, akad nikah, dan sebagainya. Sehingga tidak dapat terjadi perkawinan kalau syarat ini tidak terpenuhi. Sedangkan syarat adalah sesuatu yang harus ada dalam perkawinan, tetapi tidak termasuk

5 Hindun Annisa, Islam dan Hubungan Seksual yang Sehat, Jakarta: Yayasan Kesejateraan Fatayat (YKF) Yogyakarta Ford Soundation, 2002, hlm. 43.

6 Hasbullah Abdullah, Bahan Ajar: Hukum Islam, Kolaka: Universitas Sembilanbelas November, 2014, hlm. 27.

7 Sayuti Thalib, Hukum Kekeluargaan Indonesia, Jakarta: Yayasan Penerbit Universitas Indonesia, 1986, hlm. 17.

8 Mahmud Yunus, Hukum Perkawinan Dalam Islam, Jakarta: PT. Hidakarya Agung, 1990, hlm. 67. 
dalam hakikat perkawinan itu, kalau salah satu syarat tersebut tidak dapat terpenuhi maka perkawinan itu tidak sah.

Adapun yang menjadi rukun perkawinan dalam hukum Islam adalah:

a) Pihak yang melaksanakan perkawinan, yaitu mempelai pria dan wanita;

b) Wali dari calon istri;

c) Saksi;

d) Ijab dan Qobul.

Adapun yang menjadi syarat-syarat perkawinan menurut hukum Islam adalah:

1. Pihak-pihak yang melaksanakan perkawinan

Mempelai pria dan wanita harus memenuhi syarat-syarat tertentu supaya perkawinan yang dilaksanakan menjadi sah hukumnya. Adapun syaratsyarat yang harus dipenuhi adalah:

a) Telah balig dan mempunyai kecakapan yang sempurna. Jadi kedewasaan ini selain ditentukan oleh umur juga oleh kematangan jiwa. Sebab untuk membentuk suatu rumah tangga sebagai salah satu tujuan perkawinan itu sendiri supaya dapat dilaksanakan seperti apa yang diharapkan, maka kedua belah pihak yaitu calon suami-istri harus sudah matang jiwa raganya.

b) Berakal sehat.

c) Tidak karena paksaan. Harus berdasarkan kesukarelaan kedua belah pihak.

d) Wanita yang dikawini oleh seorang pria bukan termasuk salah satu macam wanita yang haram dinikahi (muhrim).

2. Wali dari calon istri, harus memenuhi syarat-syarat yaitu:
a) Mukallaf/balig;
b) Muslim;
c) Berakal sehat;
d) Laki-laki;
e) Adil.

3. Saksi nikah, syarat-syaratnya:
a) Mukallaf/balig;
b) Muslim 
c) Saksi harus mengerti dan mendengar perkataan-perkataan yang diucapkan pada waktu akad nikah dilaksanakan. Orang bisu dan tuli boleh diangkat menjadi saksi asal dapat memahami dan mengerti apa yang dilakukan oleh pihak yang berakad.

d) Adil, yaitu orang yang taat beragama.

e) Saksi yang hadir minimum dua orang. Saksi itu harus laki-laki, tetapi apabila tidak ada dua orang saksi laki-laki, maka boleh dihadiri satu orang saksi laki-laki dan dua orang saksi wanita.

4. Ijab dan Qobul, mempunyai syarat yaitu:

a) Dengan perkataan yang berarti perkawinan, pernikahan serta kerelaan dari pihak-pihak calon suami-istri yang melakukan perkawinan itu.

b) Perkataan qobul haruslah memakai perkataan yang menegaskan bahwa pihak calon suami telah menerima ijab yang diucapkan untuk wali pihak calon istri.

c) Ijab dan Qobul haruslah sesuai dan ada kecocokan. Ijab dan Qobul dikatakan tidak sesuai dan tidak ada kecocokan ialah apabila ijab yang diucapkan tidak sesuai dengan qobul yang diucapkan.

d) Masing-masing pihak harus mendengar dan memahami perkataan atau isyarat-isyarat yang diucapkan atau dilakukan oleh masingmasing pihak di waktu akad nikah.

e) Ijab dan qobul haruslah diucapkan di tempat yang sama dan dalam waktu yang sama.

f) Shighat akad nikah haruslah mengandung pengertian bahwa perkawinan antara calon suami dengan calon istri telah berlangsung dalam arti yang sebenarnya setelah selesai diucapkan.

g) Shighat akad nikah itu tidak ada pembatasan waktu.

Rukun dan syarat-syarat perkawinan tersebut di atas wajib dipenuhi. Apabila tidak terpenuhi maka perkawinannya tidak sah.

\section{Syarat-syarat Perkawinan menurut Undang-Undang Nomor 1 Tahun 1974 Tentang Perkawinan}

Syarat-syarat perkawinan dalam Undang-Undang Nomor 1 Tahun 1974 tentang Perkawinan diatur dalam Pasal 6 dan Pasal 7, yaitu: 
a) Perkawinan harus ada persetujuan dari kedua calon mempelai. Yang dimaksud dengan persetujuan di sini adalah bahwa perkawinan itu harus dilaksanakan berdasarkan kehendak bebas calon mempelai pria maupun calon mempelai wanita untuk melaksanakan perkawinan tanpa persetujuannya.

b) Bagi calon mempelai yang belum berumur 21 tahun harus ada ijin dari kedua orang tua atau wali.

c) Apabila kedua orang tua meninggal dunia, maka yang berhak memberi ijin adalah berturut-turut sebagai berikut: Jika kedua orang tua masih hidup, maka yang berhak memberi ijin adalah kedua-duanya. Sedangkan apabila salah satu meninggal dunia, maka yang berhak memberi ijin adalah salah satu dari keduanya yang masih hidup. Dalam hal ijin ada pada pihak orang tua perempuan, maka orang tua perempuanlah yang bertindak sebagai wali. Ketentuan Pasal 6 ayat 1 sampai dengan ayat 5 tersebut hanya berlaku bagi mereka yang agama dan kepercayaannya tidak menentukan lain (Pasal 6 ayat 6). Sehingga bagi mereka yang beragama Islam oleh karena hukum Islam telah mengenal susunan perwalian dalam perkawinan, maka ketentuan dalam Undang-Undang perkawinan ini tidak berlaku, sepanjang ketentuan-ketentuan itu bertentangan dengan ketentuan-ketentuan susunan perwalian menurut hukum Islam.

d) Apabila salah seorang dari kedua orang tua dalam keadaan tidak mampu menyatakan kehendaknya karena disebabkan di bawah kuratele, sakit ingatan, tempat tinggalnya tidak diketahui. Maka ijin dapat diberikan oleh salah satu pihak saja yang mampu menyatakan kehendaknya.

e) Apabila kedua orang tua telah meninggal dunia atau keduanya tidak mampu menyatakan kehendaknya, maka yang berhak memberi ijin adalah wali yang memelihara calon mempelai atau keluarga yang mempunyai hubungan darah dalam garis keturunan lurus ke atas selama mereka masih hidup dan dalam keadaan dapat menyatakan kehendaknya.

f) Jika ada perbedaan pendapat antara mereka yang disebut dalam ayat 2, 3, dan 4 pasal ini atau salah seorang atau lebih di antara mereka tidak ada menyatakan pendapatnya. Pengadilan dalam daerah hukum tempat tinggal orang yang hendak melaksanakan perkawinan, yang berhak memberi ijin 
dari pengadilan diberikan atas permintaan pihak yang hendak melaksanakan perkawinan setelah lebih dahulu pengadilan mendengar sendiri orang yang disebut dalam ayat 2, 3, dan 4 tersebut.

g) Batas umur untuk melaksanakan perkawinan adalah sekurang-kurangnya 19 tahun bagi calon suami dan 16 tahun bagi calon istri.

\section{Kedudukan Wali Dalam Perkawinan}

Wali dalam perkawinan adalah rukun artinya harus ada dalam perkawinan, tanpa adanya wali, maka perkawinan dianggap tidak sah. Terutama perkawinan dari orang yang belum mukallaf ${ }^{9}$. Adapun wali berdasarkan Hadist Nabi adalah dari Abu Musa, sesungguhnya Rasullulah Shallallahu 'Alaihi wa Sallam bersabda, "Tidak sah nikah tanpa Wali".10 Terdapat juga sebuah hadis yang artinya "Barang siapa di antara perempuan yang nikah dengan tidak diizinkan oleh walinya, maka nikahnya batal". ${ }^{11}$ Selain itu, juga terdapat hadis yang artinya:

"Dari Aisyah R.A. berkata: Rasulullah Shallallahu 'Alaihi wa Sallam telah bersabda: wanita mana saja yang nikah tanpa seizin wali maka nikahnya batal. Jika sang suami telah mengumpulinya maka wanita itu berhak mendapatkan maharnya lantaran telah menghalalkan kehormatannya. Jika para wali enggan menikahkan maka sultanlah yang bertindak menjadi wali bagi orang yang tidak ada walinya".12

Di Indonesia menganut pendapat dari mazhab Syafi'i13, yang berpendapat bahwa wali merupakan syarat sahnya suatu perkawinan, jadi tidak dimungkinkan terjadi perkawinan tanpa adanya wali.

\section{Macam-macam Wali}

Dari macam-macam orang yang dinyatakan berhak menjadi wali, dapat dibedakan menjadi beberapa macam wali, yaitu:

$9 \quad$ Mukallaf adalah muslim yang dikenai kewajiban atau perintah dan menjauhi larangan agama (pribadi muslim yang sudah dapat dikenai hukum). Seseorang berstatus mukalaf bila ia telah dewasa dan tidak mengalami gangguan jiwa maupun akal.

10 At-Tirmidzi, Al-Jami' al-Shohih, Kitab Nikah, Bab 14, Dar al-Fikr, Beirut Libanon, 1988, 111: 407, Hadist No. 1101, hlm. 101.

11 Ibid, hlm. 407.

12 As-Sun'ani, Subul Al-Salam, diterjemahkan oleh Abu bakar Muhammad, Surabaya, Al-Ikhlas, 1995, hlm. 427.

13 Mazhab Syafi'i adalah mazhab fikih dalam Sunni yang dicetuskan oleh Imam Syafi'i pada awal abad ke-9. Mazhab ini kebanyakan dianut pada penduduk Mesir Selatan, Arab Saudi bagian barat, Suriah, Indonesia, Malaysia, Brunei, pantai Koromandel, Malabar, Hadramaut dan Bahrain. 


\section{Wali Nashab}

Anggota keluarga laki-laki dari calon mempelai perempuan yang mempunyai hubungan darah patrilineal dengan calon mempelai perempuan. Di dalamnya termasuk ayah, kakek, saudara laki-laki, paman dan seterusnya. Wali nasab dibedakan menjadi dua, yaitu:

a) Wali nasab yang berhak memaksakan kehendaknya untuk mengawinkan calon mempelai perempuan tanpa seizin dulu dari yang bersangkutan atau disebut wali mujbir. Wali mujbir antara lain ayah, kakek, dan seterusnya ke atas. Wali mujbir diperuntukkan bagi perempuan yang belum pernah menikah.

b) Wali nasab yang tidak mempunyai kekuasaan memaksa.

\section{Wali Hakim}

Wali hakim menurut Pasal 1 huruf b Kompilasi Hukum Islam adalah wali nikah yang ditunjuk oleh Menteri Agama atau pejabat yang ditunjuk olehnya, yang diberi hak dan kewenangan untuk bertindak sebagai wali nikah. Menurut Imam Syafi'i, wali yang jauh tidak boleh menjadi wali apabila yang dekat masih ada. Dalam hal wali dekat tidak ada dan tidak ada yang mewakilinya untuk menjadi wali adalah wali hakim bukan wali yang jauh, karena wali yang dekat dianggap masih ada di bawah perwaliannya selama ia masih hidup dan tidak gila. Perwalian nasab atau kerabat pindah kepada perwalian hakim apabila terjadi:

a) Wali nasabnya tidak ada;

b) Wali nasabnya bepergian jauh atau tidak ada di tempat tetapi tidak memberi kuasa kepada wali yang lebih dekat yang ada;

c) Wali nasab kehilangan hak perwaliannya;

d) Wali nasab sedang berihram atau umrah;

e) Wali nasab menolak bertindak sebagai wali atau adhal; dan

f) Wali nasab menjadi mempelai laki-laki dari orang yang ada di bawah perwaliannya.

\section{Wali Adhal}

Wali yang menolak atau tidak bersedia menikahkan disebut dengan istilah wali adhal. Menurut para ulama definisi wali adhal adalah penolakan wali untuk menikahkan anak 
perempuannya yang berakal dan sudah balig dengan laki-laki yang sepadan dengan perempuan itu. Wali adhal dinyatakan apabila: ${ }^{14}$

(1) Adanya penolakan (keengganan) wali untuk menikahkan calon mempelai perempuan;

(2) Telah ada permintaan atau permohonan dari calon mempelai perempuan agar dirinya dinikahkan dengan calon mempelai laki-laki;

(3) Adanya perasaan saling menyayangi atau mencintai di antara masingmasing calon mempelai;

(4) Alasan penolakan atau keengganan wali tersebut bertentangan dengan hukum Islam.

Ketentuan mengenai wali adhal dalam hukum perkawinan Indonesia diatur dalam beberapa peraturan perundang-undangan, yaitu:

(1) Kompilasi Hukum Islam (KHI). Ketentuan wali adhal dalam Kompilasi Hukum Islam diatur dalam Pasal 23;

(2) Peraturan Menteri Agama Nomor 30 Tahun 2005 tentang Wali Hakim. Dinyatakan bahwa adhal-nya wali merupakan salah satu syarat atau keadaan dibolehkannya wali hakim sebagai wali dalam perkawinan calon mempelai perempuan dengan calon mempelai laki-laki. Untuk menyatakan adhal-nya wali, maka diperlukan penetapan dari Pengadilan Agama yang mewilayahi tempat tinggal calon mempelai perempuan;

(3) Peraturan Menteri Agama Nomor 11 Tahun 2007 tentang Pencatatan Nikah. Penetapan bahwa seorang wali dinyatakan adhal harus didasarkan pada pertimbangan yang sesuai dengan hukum Islam. Adapun Peraturan Menteri Agama Nomor 2 Tahun 1987 tentang Wali Hakim dalam Pasal 1 huruf b menyatakan bahwa: "Wali hakim adalah pejabat yang ditunjuk oleh Menteri Agama atau pejabat yang ditunjuk olehnya untuk bertindak sebagai wali nikah bagi calon mempelai wanita yang tidak mempunyai wali". Sedangkan dalam Pasal 4 Peraturan Menteri Agama Nomor 2 Tahun 1987 tentang Wali Hakim menyatakan bahwa: "Kepala Kantor Urusan Agama Kecamatan selaku Pegawai Pencatat Nikah ditunjuk menjadi wali hakim dalam wilayahnya untuk menikahkan mempelai wanita sebagaimana dimaksudkan Pasal 2 ayat 1 peraturan ini".

14 Wahbah al Zuhaili, al Fiqh al Islam wa Adillatuhu, Juz 9, terj. Abdul Hayye al Kattani, Jakarta: Gema Insani, 2011, hlm. 470. 
Berdasarkan rumusan pasal tersebut di atas maka di Indonesia yang bertindak sebagai wali hakim adalah Kepala Kantor Urusan Agama Kecamatan.

\section{Wali Muhakam}

Wali Muhakam adalah seseorang yang diangkat oleh kedua calon suami-istri untuk bertindak sebagai wali dalam akad nikah mereka. Suatu perkawinan yang seharusnya dilaksanakan dengan wali hakim, padahal di tempat itu tidak ada wali hakimnya, maka pernikahan dilangsungkan dengan wali muhakam. Dengan cara kedua calon pengantin mengangkat seorang yang mempunyai keilmuan tentang hukum-hukum untuk menjadi wali dalam pernikahan mereka. Syarat-syarat menjadi wali muhakam adalah orang lain yang Islam, laki-laki, terpandang, disegani, luas ilmu agamanya terutama tentang perkawinan, dan adil. ${ }^{15}$

Kasus wali adhal berdasarkan Putusan Pengadilan Agama Kolaka Nomor: 2/Pdt.P/2010/PA Klk., yakni Pengadilan Agama Kolaka yang memeriksa dan mengadili perkara wali adhal yang diajukan oleh pemohon. Adapun duduk perkaranya adalah Pemohon hendak melangsungkan pernikahan dengan laki-laki berusia 40 tahun. Tetapi, ayah pemohon menolak dengan alasan laki-laki tersebut mempunyai 9 (sembilan) orang istri.

Berdasarkan penolakan tersebut, pemohon dan calon suami pemohon diberikan surat penolakan untuk dinikahkah dari Kepala KUA Kec. Kolaka. Atas dasar surat tersebut, pemohon memohon kepada Pengadilan Agama Kolaka untuk diperiksa. Membaca surat permohonan pemohon tanggal 10 Desember 2010 yang diajukan kepada Ketua Pengadilan Agama Kolaka, kemudian terdaftar dalam buku register perkara permohonan di bawah register Nomor: 2/Pdt.P/2010/PA Klk., dimana pemohon memohon kepada Ketua Pengadilan Agama Kolaka untuk memeriksa dan mengadili perkara agar berkenan untuk:

1. Mengabulkan permohonan Pemohon;

2. Menyatakan adhal-nya wali pemohon;

3. Mengizinkan pemohon untuk menikah dengan calon suaminya dengan wali hakim;

4. Membebankan biaya perkara menurut hukum.

15 Alwi Sihab, "Peran Kiai Sebagai Wali Muhakam”, Al-Ahwal Al-Syakhsiyyah, Vol 1 No. 1, November 2013. hlm. 11. 
Pada salinan Penetapan Pengadilan Agama Kolaka Nomor: 2/Pdt.P/2010/PA Klk., disebutkan beberapa pertimbangan hakim yaitu:

1. Pada hari persidangan yang telah ditentukan pemohon hadir di persidangan, sedang orang tua/wali Pemohon tidak datang menghadap dan tidak pula menyuruh orang lain menghadap sebagai kuasanya;

2. Majelis Hakim telah berusaha menasihati pemohon agar bersabar dan meminta persetujuan kembali pada orang tua/wali pemohon, akan tetapi tidak berhasil;

3. Pemohon mengajukan bukti-bukti terlebih dahulu ibu kandung pemohon memberikan keterangan dalam persidangan yang pada pokoknya menyatakan bahwa ayah kandung/wali pemohon tidak akan memberikan perwalian kepada Pemohon untuk menikah dengan laki-laki calon suaminya, karena laki-laki tersebut masih terlibat perkawinan dengan perempuan lain.

Selain itu, pertimbangan majelis hakim juga didukung keterangan 3 (tiga) orang saksi, sebagai berikut:

1. Saksi Pertama, sebagai tante Pemohon, yang salah satu kesaksiannya menerangkan orang tua laki-laki pemohon menolak pernikahan tersebut karena telah mendengar informasi bahwa calon suami pemohon mempunyai 9 (sembilan) orang istri;

2. Saksi Kedua, sebagai Lurah Watuliandu, yang salah satu kesaksiannya menerangkan orang tua laki-laki pemohon menolak pernikahan tersebut karena calon suami pemohon mempunyai 9 (sembilan) orang istri;

3. Saksi Ketiga, sebagai Paman Pemohon, yang salah satu kesaksiannya menerangkan bahwa orang tua laki-laki pemohon menolak pernikahan tersebut karena calon suami pemohon mempunyai istri lebih dari satu orang.

Berdasarkan keterangan di atas, maka Majelis Hakim menimbang dan menemukan fakta-fakta hukum sebagai berikut:

1. Pemohon dan calon suami pemohon sudah saling mengenal dan saling mencintai selama 6 (enam) bulan; 
2. Pemohon tidak ada halangan untuk menikah baik dari segi hukum maupun dari segi syar'i dan tidak ada pula hubungan baik wajib, semenda atau sesusuan;

3. Penolakan orang tua pemohon untuk menjadi wali dalam pernikahan Pemohon dengan laki-laki calon suaminya dinilai tidak beralasan, oleh karena berdasarkan bukti fotokopi akta cerai Nomor: 120/AC/2010/PA.Klk dari calon suami pemohon tanggal 18 Agustus 2010, menerangkan bahwa calon suami Pemohon tidak terikat lagi dengan perkawinan yang sah menurut hukum;

4. Majelis hakim berpendapat bahwa demi kemaslahatan Pemohon bersama calon suami pemohon maka dipandang perlu untuk mencabut kekuasaan orang tua/ayah kandung Pemohon sebagai wali dan menyerahkan kepada KUA Kec. Kolaka, selaku pegawai Pencatat Nikah untuk menikahkan Pemohon dengan calon suaminya.

Dengan memperhatikan peraturan perundang-undangan yang berkenaan dengan perkara tersebut, maka dewan hakim menetapkan:

1. Mengabulkan permohonan Pemohon;

2. Menyatakan adhal wali nikah Pemohon;

3. Mengizinkan Pemohon untuk melakukan pernikahan dengan calon suaminya, dengan wali hakim;

4. Membebankan biaya perkara kepada Pemohon sebesar Rp. 341.000,- (tiga ratus empat puluh satu ribu rupiah).

Adapun analisis penulis terhadap keabsahan perkawinan dengan wali adhal berdasarkan putusan Pengadilan Agama Kolaka Nomor: 2/Pdt.P/2010/PA Klk., sebagai berikut.

Keadilan Substantif Hakim Dalam Putusan Pengadilan Agama Kolaka Nomor: 2/Pdt.P/2010/PA Klk.

Majelis hakim Pengadilan Agama Kolaka dalam menetapkan atau menolak adhal-nya wali harus berijtihad untuk menetapkan apakah wali nasab adhal atau tidak. Sehingga dalam hal ini alasan dan dasar yang digunakan hakim tergantung pada kasusnya.

Pada Putusan Pengadilan Agama Kolaka Nomor 2/Pdt.P/2010/PA Klk., dijelaskan bahwa pemohon mengajukan beberapa bukti yang salah satunya adalah fotokopi akta 
cerai nomor: 120/AC/2010/PA.Klk dari calon suami pemohon tanggal 18 Agustus 2010 sebagai bukti ini menjelaskan bahwa secara hukum positif calon suami pemohon telah resmi bercerai dengan seorang wanita. Selain itu, majelis hakim dihadapkan oleh 3 (tiga) orang saksi. Saksi pertama yang dalam persidangan di bawah sumpah memberikan kesaksian bahwa saksi orang tua laki-laki Pemohon membatalkan rencana pernikahan tersebut karena orang tua laki-laki pemohon telah mendengar informasi bahwa calon suami pemohon mempunyai istri 9 (sembilan) orang. Saksi kedua yang dalam persidangan di bawah sumpah memberikan kesaksian bahwa saksi orang tua laki-laki Pemohon membatalkan rencana pernikahan tersebut karena orang tua laki-laki pemohon telah mendengar informasi bahwa calon suami pemohon mempunyai 9 (sembilan) orang istri. Saksi ketiga yang dalam persidangan di bawah sumpah memberikan kesaksian bahwa saksi orang tua laki-laki Pemohon membatalkan rencana pernikahan tersebut karena orang tua laki-laki pemohon telah mendengar informasi bahwa calon suami pemohon mempunyai istri lebih dari satu orang.

Berdasarkan dari keterangan ketiga saksi tersebut menerangkan bahwa para saksi hanya mendengar informasi dari orang tua pemohon bahwa calon suami pemohon memiliki istri lebih dari satu orang, tetapi tidak ada satu pun saksi yang dapat membuktikan bahwa calon suami pemohon benar memiliki 9 (sembilan) orang istri.

Dalam salinan penetapan Pengadilan Agama Kolaka Nomor: 2/Pdt.P/2010/PA Klk., ayah pemohon tidak berkenan hadir dalam persidangan, selain itu calon suami pemohon juga tidak menjadi saksi dalam persidangan tersebut. Sehingga majelis hakim hanya dapat memeriksa terkait fakta dalam persidangan dari bukti apa yang dihadapkan padanya, yaitu bukti-bukti yang disampaikan oleh Pemohon maupun keterangan para saksi.

Penulis berpendapat bahwa akibat dari orang tua pemohon tidak menghadiri persidangan untuk menjadi saksi, menjadikan alasan bagi hakim untuk melakukan upaya hukum berupa verstek ${ }^{16}$ yaitu memutuskan adhal-nya wali dan menerima permohonan pemohon. Hal ini terlihat dari keterangan para saksi dalam persidangan dan di bawah sumpah bahwa tidak ada yang dapat membuktikan bahwa calon suami pemohon benar memiliki 9 (sembilan) orang istri. Sehingga di dalam persidangan membuktikan bahwa calon suami pemohon memiliki 9 (sembilan) orang istri adalah tidak benar.

16 Verstek adalah putusan yang dijatuhkan oleh Majelis Hakim tanpa hadirnya tergugat dan tanpa alasan yang sah meskipun telah dipanggil secara resmi dan patut. 
Memperhatikan pertimbangan alasan keadilan substantif hakim sebagaimana dalam salinan penetapan Pengadilan Agama Kolaka Nomor: 2/Pdt.P/2010/PA Klk., sebagai berikut:

1. Pemohon dan calon suami pemohon sudah saling mengenal dan saling mencintai selama 6 (enam) bulan;

2. Pemohon tidak ada halangan untuk menikah baik dari segi hukum maupun dari segi syar'i dan tidak ada pula hubungan baik wajib, semenda atau sesusuan;

3. Penolakan orang tua pemohon untuk menjadi wali dalam pernikahan Pemohon dengan calon suami pemohon dinilai tidak beralasan, oleh karena berdasarkan bukti fotokopi akta cerai nomor: 120/AC/2010/PA.Klk bahwa calon suami pemohon tidak terikat lagi dengan perkawinan yang sah menurut hukum;

4. Majelis hakim berpendapat bahwa demi kemaslahatan Pemohon bersama calon suami pemohon maka dipandang perlu untuk mencabut kekuasaan orang tua/ayah kandung Pemohon sebagai wali dan menyerahkan kepada KUA Kec. Kolaka, selaku pegawai Pencatat Nikah untuk menikahkan Pemohon dengan calon suaminya.

Atas dasar putusan majelis hakim Pengadilan Agama Kolaka Nomor 2/Pdt.P/2010/PA Klk., Kepala KUA ditunjuk sebagai wali hakim untuk menikahkan pemohon dengan calon suami pemohon. Sehingga, penulis berpendapat bahwa majelis hakim telah benar menetapkan orang tua pemohon yang dalam hal ini adalah ayah pemohon sebagai wali adhal. Sebagaimana dalam Pasal 2 ayat 3 Peraturan Menteri Agama Nomor 2 Tahun 1987 Tentang Wali Hakim yakni Pengadilan Agama memeriksa dan menetapkan adhal-nya Wali dengan cara singkat atas permohonan calon mempelai wanita dengan menghadirkan wali calon mempelai wanita.

\section{Pelaksanaan Perkawinan Pemohon}

Dalam Pasal 2 Undang-Undang Nomor 1 tahun 1974 tentang Perkawinan yang berbunyi:

(1) Perkawinan adalah sah apabila dilakukan menurut hukum masing-masing agama dan kepercayaannya itu;

(2) Tiap-tiap perkawinan dicatat menurut peraturan perundang-undangan yang berlaku. 
Pasal ini menjelaskan bahwa perkawinan dinyatakan sah apabila dilakukan menurut hukum agama dan kepercayaan dari kedua calon mempelai serta perkawinan tersebut dicatat menurut peraturan perundang-undangan yang berlaku. Selan itu, dalam hukum perkawinan Islam diatur mengenai rukun perkawinan, yaitu hakikat dari suatu perkawinan, supaya perkawinan dapat dilaksanakan maka harus dipenuhi rukunrukunya. Adapun rukun perkawinan adalah pihak yang melaksanakan akad nikah, yaitu mempelai pria dan wanita; Wali; Saksi; dan Akad nikah. ${ }^{17}$

Hasil penelitian penulis, dengan memperhatikan:

(1) Surat keterangan untuk nikah nomor 474.2/06/2011 tertanggal 24 Januari 2011 yang ditandatangani oleh Lurah Watuliadu, Kecamatan Kolaka, Kabupaten Kolaka yang isi surat tersebut menerangkan bahwa calon suami pemohon akan melakukan perkawinan dengan pemohon;

(2) Daftar Pemeriksaan Nikah Nomor Akta Nikah: 45/13/1/2011 tertanggal 17 Januari 2011 yang menerangkan bahwa:

a. Akad nikah dilangsungkan pada hari Kamis, 27 Januari 2011 bertepatan dengan 21 Shafar $1432 \mathrm{H}$.

b. Yang bertindak sebagai wali nikah adalah Kepala Kantor Urusan Agama Kecamatan Kolaka yang dalam hal ini sebagai wali hakim, berdasarkan Putusan Pengadilan Agama Kolaka Nomor: 2/Pdt.P/2010/PA Klk.

c. Maskawin berupa sebidang tanah perkebunan seluas $1 / 2 \mathrm{Ha}$., dibayar tunai

d. Yang bertindak sebagai Saksi I dalam perkawinan ini adalah seorang laki-laki, umur 42 tahun, warga negara Indonesia, agama Islam, perkerjaan sebagai Lurah, bertempat tinggal di Jl. Sultan Hasanuddin.

e. Yang bertindak sebagai Saksi II dalam perkawinan ini adalah seorang laki-laki, umur 37 tahun, warga negara Indonesia, agama Islam, perkerjaan PNS, bertempat tinggal di Jl. Kasuari.

Sehubungan dengan beberapa bukti yang ada, maka perkawinan yang dilakukan oleh Pemohon dengan calon suami pemohon telah sesuai dengan Pasal 2 Undang-Undang Nomor 1 tahun 1974 tentang Perkawinan. Selain itu perkawinan tersebut juga telah sesuai dengan hukum Islam karena memenuhi rukun perkawinan yaitu ada mempelai pria dan

17 Soemiyati, Hukum Perkawinan Islam... Op.Cit, hlm. 30. 
wanita; ada wali yang dalam hal ini adalah wali hakim; ada 2 (dua) orang saksi; dan ada akad nikah.

Sehingga, hasil analisis penulis menyatakan bahwa perkawinan dengan wali adhal berdasarkan putusan Pengadilan Agama Kolaka Nomor: 2/Pdt.P/2010/PA Klk. adalah sah.

Perkawinan merupakan kebutuhan dari setiap orang, untuk itu apabila telah mampu menikah harus segera menikah. Tidak sewajarnya wali nasab menolak dan menghalangi perkawinan anaknya untuk menikah dengan lelaki pilihannya sendiri dengan alasan yang tidak benar adanya. Selain itu, pemohon dan calon suami pemohon telah bekerja dan telah cukup umur serta telah siap untuk menjalin hubungan dalam perkawinan. Untuk mencegah terjadinya perbuatan dosa dan hal-hal yang tidak diinginkan dari kejadian tersebut adalah dengan melaksanakan perkawinan meskipun walinya adhal.

\section{KESIMPULAN}

Kesimpulan dari penulisan ini adalah pertimbangan keadilan substantif Hakim dalam Putusan Pengadilan Agama Kolaka Nomor: 2/Pdt.P/2010/PA Klk. dalam menetapkan adhal-nya wali, penulis menilai sangat tepat. Hal ini dikarenakan dalam fakta persidangan sebagaimana dalam Putusan Pengadilan Agama Kolaka Nomor: 2/Pdt.P/2010/Pa Klk., tidak membuktikan bahwa calon suami pemohon memiliki 9 (sembilan) orang istri, sehingga orang tua pemohon menolak untuk menikahkan pemohon dinilai tidak beralasan. Pemohon dan calon suami pemohon tidak ada alasan syar'i yang melarang untuk menikah serta kedua mempelai telah bekerja dan telah cukup umur serta telah siap untuk menjalin hubungan dalam perkawinan. Agar tidak terjadi perbuatan dosa dan halhal yang tidak diinginkan dari kejadian tersebut adalah dengan melaksanakan perkawinan meskipun walinya adhal menjadi wali nikah. Selain itu, perkawinan yang dilakukan telah sesuai dengan hukum Islam karena telah memenuhi rukun-rukunnya. Sehingga, perkawinan dengan wali adhal berdasarkan putusan Pengadilan Agama Kolaka Nomor: 2/Pdt.P/2010/PA Klk. adalah sah. 


\section{Daftar Pustaka}

\section{Buku}

Abdullah, Hasbullah, Bahan Ajar: Hukum Islam, Kolaka: Universitas Sembilanbelas November, 2014.

al Zuhaili, Wahbah, al Fiqh al Islam wa Adillatuhu, Juz 9, terj. Abdul Hayye al Kattani, Jakarta: Gema Insani, 2011.

Annisa, Hindun, Islam dan Hubungan Seksual yang Sehat, Jakarta: Yayasan Kesejateraan Fatayat (YKF) Yogyakarta Ford Soundation, 2002.

As-Sun'ani, Subul Al-Salam, diterjemahkan oleh Abu bakar Muhammad, Surabaya, AlIkhlas, 1995.

At-Tirmidzi, Al-Jami' al-Shohih, Kitab Nikah, Bab 14, Dar al-Fikr, Beirut Libanon, 1988, 111: 407, Hadist No. 1101.

Marzuki, Peter Mahmud, Penelitian Hukum, Jakarta: Kencana Prenada Media Group, 2011. Soemiyati, Hukum Perkawinan Islam dan Undang-Undang Perkawinan, Yogyakarta: Liberty, 1986.

Syahar, Saidus, Undang-Undang Perkawinan dan Masalah Pelaksanaannya, Bandung: Alumni, 1981.

Thalib, Sayuti, Hukum Kekeluargaan Indonesia, Jakarta: Yayasan Penerbit Universitas Indonesia, 1986.

Yunus, Mahmud, Hukum Perkawinan Dalam Islam, Jakarta: PT. Hidakarya Agung, 1990.

\section{Jurnal}

Sihab, Alwi, "Peran Kiai Sebagai Wali Muhakam", Al-Ahwal Al-Syakhsiyyah, Vol 1 No. 1, November 2013.

\section{Peraturan Perundang-undangan}

Undang-Undang Dasar Negara Republik Indonesia Tahun 1945.

Undang-Undang Republik Indonesia Nomor 1 Tahun 1974 tentang Perkawinan (Lembaran Negara Republik Indonesia Tahun 1974 Nomor 1, Tambahan Lembaran Negara Republik Indonesia Nomor 3019).

Instruksi Presiden Republik Indonesia Nomor 1 Tahun 1991 Tentang Penyebarluasan Kompilasi Hukum Islam (Lembaran Lepas Sekretariat Negara Tahun 1991).

Peraturan Menteri Agama Republik Indonesia Nomor 30 Tahun 2005 tentang Wali Hakim. 
Salinan Penetapan Pengadilan Agama Kolaka Nomor: 2/Pdt.P/2010/PA Klk.

\section{Situs Web}

Sholeh, Muhammad, "Kata MUI Soal Pria yang Beristri Lebih dari Empat”, Merdeka.com, https://www.merdeka.com/peristiwa/kata-mui-soal-pria-yang-beristri-lebihdari-empat.html, diakses pada tanggal 28 Juni 2020. 